\title{
Factors associated with the delay in seeking legal abortion for pregnancy resulting from rape
}

\begin{abstract}
Márcia de Toledo Blake ${ }^{1 *}$, Jefferson Drezett ${ }^{1,2}$, Gilzane Santos Machi ${ }^{1}$, Valdelias Xavier Pereira, ${ }^{1,3}$, Rodrigo Daminello Raimundo ${ }^{1,3}$, Fernando Rocha Oliveira ${ }^{1,3}$, Luis Fernando Barbosa Tavares ${ }^{1}$, Francisco Winter dos Santos Figueiredo', Laércio da Silva Paiva', Vicente Sarubbi Junior ${ }^{4}$, Fernando Adami ${ }^{1}$, Luiz Carlos de Abreu ${ }^{1,4}$
\end{abstract}

\section{Abstract}

Background: About 7\% of rape cases in Brazil result in pregnancy. Overall, Brazilian women are unaware of the right to legal interruption of pregnancy after rape, so they delay in applying the procedure to get a legal abortion or at the end they try to abort in a condition that may be unsafe.

Objective: To analyse factors associated with the leadtime to have a legal abortion after rape.

Methods: This is a cross-sectional study. The data were collected from electronical medical records of 1,270 women who requested legal abortion in a public hospital in São Paulo during the period of 1994 to 2013. The variables age, education, race, marital status, religion, form of intimidation, vulnerable condition, perpetrator of sexual violence, number of perpetrators, and police report were analysed in relation to gestational age, according to multiple multinomial logistic regression models.

Results: The delay in requesting abortion at intermediate gestational age is associated to when a female is vulnerable $(p=0.015)$, late gestational age is associated with the presence of a police report $(p=0.029)$ and marital status as single $(p=0.05)$. Be a relative of the aggressor is associated with both intermediate $(p=0.016)$ and late gestational age $(p=0.002)$.
1 Departamento de Saúde da Coletividade, Disciplina de Metodologia Científica, Laboratório de Delineamento de Estudos e Escrita Científica, Faculdade de Medicina do $A B C$, Santo André, SP, Brazil.

2 Núcleo de Programas Especiais do Hospital Pérola Byington, São Paulo, SP, Brazil.

3 Programa de Pós-graduação em Epidemiologia, Universidade Federal de São Paulo, São Paulo, SP, Brazil.

4 Programa de Pós-graduação em Saúde Pública, Faculdade de Saúde Pública, Universidade de São Paulo, São Paulo, SP, Brazil.

Contact information:

Márcia de Toledo Blake.

Avenida Brigadeiro Luiz Antônio 683, $2^{\circ}$ andar. Bela Vista, São Paulo - SP,

Brasil. CEP 01317-001

ほ marciablake9@yahoo.com.br 
Conclusion: Females without partners, who suffered intimidation with threats, in a vulnerable condition, who made a police report and, above all, who were raped by relatives, composed the group who took longer to get the health service.

\section{Keywords}

Sexual violence; rape; unwanted pregnancy; legal abortion; women's health

\section{Background}

Sexual crimes particularly affect vulnerable young females and may be associated with physical trauma, mortality, sexual disorders, unwanted pregnan$c y$, and psychological consequences. Damages to reproductive health include increased risk of infertility, anogenital cancer, and sexually transmitted diseases (STDs) [1]. In addition to representing a public health problem in developing countries, the subject of discussing the conflict of interrupting an unwanted pregnancy, as a consequence of a rape or not, requires a well informed decision making proccess, covering the scope of legal, moral, religious, social, and cultural aspects that are linked to it [2].

Emerging data on violence against females around the world suggest that in some countries, one in five female suffer rape or attempted rape in their lifetime. Recent research on the behaviour, attitudes, and sexual experiences of young people in areas of Africa, Asia, and Latin America revealed that between 5 and $20 \%$ of females' first sexual experience was forced. Regardless of whether they have access to contraception, a forced sexual act is usually unprotected, exposing females not only to unwanted pregnancy but also to STDs, including HIV [3].

In Brazil, about $7 \%$ of rape cases resulted in pregnancy. Under Brazilian law, the victim of this type of violence has the right to abort. However, $67.4 \%$ of females who were pregnant after being raped didn't get the access to legal abortion in a public hospital [4]. Although women have the right to legal termination of pregnancy, most of them are unaware of this law and end up trying to have an abortion unsafely. According to the data recorded by the Ministry of Health in the 7th Annual Public Security of the Brazilian Forum of Public Security 2013, the number of legal abortions performed by the public hospitals network of Brazil reached 1,504 procedures in the year 2011, 1,625 in 2012, and 1,400 in 2013 [5].

The delay verified in the decision to search for legal termination of pregnancy cannot be attributed to or explained by the cost of abortion in Brazil. The Brazilian Unified Health System (SUS) ensures full and free coverage for abortion in these cases, regardless of the woman has any sort of health insurance. Therefore, the females who have participated in this study did not face any financial barriers to make legal abortion.

According to the Allan Guttmacher Institute, the highest rates of abortions were observed between 1995 and 2008 mainly in those regions where laws against abortion are more rigid. In 2008, an average of 28 women per thousand carried out an abortion, indicating a decrease in relation to 1995 , when the rate was 35 women per thousand. However, the number of pregnancies interrupted by unsafe practices that posed risks to women's health grew in the analysed period from $44 \%$ to $49 \%$ [6].

The technical rule of the Brazilian Ministry of Health (version updated in 2011) states the efficien- 
cy of mechanisms of prevention is greater the earlier they are adopted. In this case, it is understood that 72 hours after sexual assault is the deadline for the introduction of drugs to prevent unwanted pregnancy and STDs/HIV [7].

The situation of rape imposes varying degrees of embarrassment to victims, thus inhibiting their attendance to the police and even to the health service. Therefore, it is essential to obtain data that will assist the practitioner in the difficult task of reducing the consequences of such a painful situation, identifying the possible reasons linked to the delay in accessing hospital services [8].

An estimated 60,000-70,000 women die annuaIly from complications of unsafe abortion, with procedures performed by persons lacking the necessary skills and/or in environments not in conformity with minimal medical standards. Hundreds of thousands suffer long-term consequences, including chronic pelvic pain and infertility. The reasons for the continuing high incidence of unwanted pregnancy leading to unsafe abortion include lack of access, misuse or failure of effective contraception, misinformation, and forced sex, which prevent women from protecting themselves. Unsafe abortion is closely associated with restrictive legal environments and administrative and political barriers that impede access to existing services [3].

The literature review showed that studies generally discuss only aspects indirectly related to late abortion after rape, emphasizing how different policies can help to avoid late and unsafe procedure [9].

The discussion about legal abortion on advanced gestational age pointed to the need to investigate which factors could hinder directly or indirectly the decision of these females in seeking the procedure after of being victims of rape.

\section{Methods}

\section{Study design}

This is a cross-sectional study. The records included patients regularly enrolled at the Centro de Referência da Saúde da Mulher - Hospital Pérola Byington, located in Sao Paulo, Brazil, assisted by the Núcleo de Atenção Integral à Mulher em Situação de Violência Sexual (Núcleo AVS) (Center of Integral Assistance to Women in Situation of Sexual Abuse) between July 1994 and April 2013, with pregnancy resulting from rape and request for legal termination of pregnancy. Data collection took place between 2011 and 2013 from the electronic database of the hospital.

\section{Criteria for selection and inclusion of subjects}

The data of the studied population, consisted of pregnant women receiving public health service, were taken from the statistics and health information of the Hospital Pérola Byington.

For the study, the data were split in the three groups categorized by the WHO (2003) related to gestational age at entry to care (Table 1). Gestational age was determinated by further examination of obstetric ultrasonography performed at the hospital and its result was recorded in the medical records of each patient.

The selection criteria for the three study groups adopted the sequential identification and review of

Table 1. Classification of study groups by gestational age and complementary criterion in admission to care according to the classification of the World Health Organization [2003].

\begin{tabular}{|c|c|c|}
\hline Group & Gestational Age & Complementary criterion \\
\hline I & $\leq 12$ weeks & - \\
\hline II & $\geq 13$ and $\leq 22$ weeks & estimated foetal weight $<500$ grams \\
\hline III & $\geq 23$ weeks & estimated foetal weight $\geq 500$ grams \\
\hline
\end{tabular}


medical charts of Núcleo AVS, maintained by the Service Medical Records of the hospital and numbered in accordance with the medical records with information provided by the patient and/or her legal representative during the interview held by the Núcleo AVS multidisciplinary team, comprising professionals of gynaecology, psychology, and social work.

After applying the inclusion and exclusion criteria (Table 2), the sample consisted of 1,270 cases for the study period. Because it is a convenience sample, the results can contribute to the study of populations with a similar profile of pregnant females who sought the Hospital Pérola Byington.

The characterization of the sexual crime of rape was made upon a complaint by the patient and/or her legal representative consistent with the provisions of Articles 213 and 217-A of Brazilian criminal law, provided by Law Nr. 12,015 of August 12, 2009. Article 213 criminalizes as rape any non-consensual sexual act committed with the use of physical force or serious threat. Article 217-A, dealing with rape of vulnerable individuals, includes sexual acts against children under 14 years or against those of any age who cannot offer resistance or give consent. Considering part of the sample prior to 2009 and, therefore, preceding the new Brazilian penal concepts, sexual crimes provided by old Articles 214 and 224 were also considered legally analogous to current Articles 213 and 217-A of the Brazilian Penal Code.

The request by the patient and/or her legal representative to have an induced abortion was ba- sed on item II of Article 128 of Brazilian law. The assessment procedure and the approval of the request of abortion complied with the provisions of Ordinance MS/GM Nr. 1,508 of the Brazilian Ministry of Health, September 1, 2005, establishing the procedures of justification and authorization for termination of pregnancy in such cases.

The age limit adopted for the children/adolescent group (age $\geq 10$ ) was different from that defined by MeSH terms (13-18 years old), but in line with the criterion used by the World Health Organization (WHO) [10], as regulated by the Brazilian Ministry of Health to meet legal definitions of sex crimes.

Rape cases involving children and/or adolescents under 18 years old contained a copy of the Rape cases involving children/adolescent under 18 years old contained a copy of the communication to the Guardian Council, in accordance with Article 13 of the Estatuto da Criança e do Adolescente (1993). Cases included from 2004 contain the Compulsory Notification determined by Decree Law 5,099 of June 3, 2004.

The study period was chosen for convenience of data collection. However, there has been no significant change in Brazilian criminal law or in the statistics on sexual violence since the period when our data were collected.

To be included in this study the hospital did not require the police report nor a report from Medical Legal Institute as elements for getting approval of legal abortion. The patient's right to choose and/or

Table 2. Criteria for inclusion and exclusion of records analysed for the study.

\begin{tabular}{l|l}
$\begin{array}{l}\text { Inclusion } \\
\text { - Sex crime of rape }\end{array}$ & - Medical records unreadable or with incomplete information \\
$\begin{array}{l}\text { - Request by the patient and/or her legal } \\
\text { representative for legal reason for } \\
\text { induced abortion }\end{array}$ & $\begin{array}{l}\text { Request for legal abortion for the exclusive condition of risk of death for the } \\
\text { mother, per paragraph I of Article } 128 \text { of the Brazilian Penal Code. }\end{array}$ \\
\hline - Age $\geq 10$ years at entry to care & $\begin{array}{l}\text { - Request for abortion for the exclusive situation of pregnancy associated with } \\
\text { severe foetal abnormality and incompatible with extra uterine life, independent } \\
\text { of the submitted court order. }\end{array}$
\end{tabular}


her legal representative from complying with these measures was observed as determined by Brazilian criminal law. By the same principles did not fit initiative or legal obligation of the researcher in charge to report the occurrence of rape to the police authority [11].

\section{Instruments}

Data were collected from an organized database in Microsof Excell 2010 program and subsequently transferred to Stata 11.1 software for analysis. The supply of the database was performed by means of additional pre-coded form for control of the cases of legal abortion after rape, adopted by the health service. The information contained in this supplement form was agreed between the interdisciplinary team directly responsible for care, consisting of medical, social workers and psychologists.

Registration in the additional form was based on the patients' reports and/or their legal representative contained in the medical records. The contents of the police report or the expert examination report of the Instituto Médico Legal (IML) (Institute of Legal Medicine), when available, helped in the record of this information.

All supplementary forms were submitted to a final review of the service, with possible correction performed by a second evaluator before typing. Because it is a database for control of the cases assisted by the institution, double typing was not carried out. However, each case included in the database was previously submitted to review of consistency of each information by a reviewer different from the responsible for typing. The divergences identified at this stage were corrected in Microsof Excell 2010 database before transferring to the Stata 11.1 program.

\section{Statistical analysis}

Given the non-normality of the data (Shapiro-Wilk; $p<0.05)$, we chose to describe the quantitative variables by median and percentiles (25 and 75), and qualitative variables using absolute and relative (\%) frequency. Associations of categorical variables were performed using the chi-square test. The independent variables age, education, race, marital status, religion, form of intimidation, vulnerable condition, perpetrator of sexual violence, number of perpetrators, and submission of police report were analysed in relation to the dependent variable gestational age at entry to care according to multiple multinomial regression models with robust variance and stepwise forward strategy for entry into the multivariate model being analysed for the reasons of crude and adjusted prevalence. The statistical program used was Stata 11.0 $[12,13]$.

\section{Ethical aspects}

The study was approved by the Research Ethics Committee of the Hospital Pérola Byington, protocol nr 051/11 in November 2011, and conducted according to the ethical standards established by the Declaration of Helsinki.

\section{Results}

The results were obtained by the association of sociodemographic characteristics of 1,270 cases of pregnant patients who requested legal abortion at the Centro de Referência da Saúde da Mulher Hospital Pérola Byington with gestational age distributed $<13$ weeks, $\geq 13-22$ weeks and $\geq 23$ weeks. The patients were between 10 and 46 years old, most with incomplete primary education, white, single, religious, and living in the metropolitan area of São Paulo, Brazil.

The caucasian were predominant among the patients $(58.27 \%)$, compared to non-caucasian $(41.73 \%)$ and single $(86.61 \%)$ were predominant compared to married (13.39\%). The religious were predominant $(80,94 \%)$ compared to not religious (13.62\%). Considering the aggressors, the unknown were predominant (62.05\%) compared to known 


\section{INTERNATIONAL ARCHIVES OF MEDICINE \\ Section: Global Health \& Health Policy \\ ISSN: 1755-7682}

Vol. 8 No. 29

doi: $10.3823 / 1628$

not relatives - identifiable aggressors (10.39\%), community member (5.59\%), former intimate partner (3.46\%) and co-worker or superior (1.81\%) - and relative - stepfather (3.46\%), current intimate partner (3.07\%), biological father $(2.44 \%)$, uncle $(1.89 \%)$, brother $(1.57 \%)$, cousin $(1.50 \%)$ and brother-in-law (0.79\%) (Table 3).

The number of pregnant females aged under 20 who seek the service later is almost three times higher $(9.4 \%)$ when compared to pregnant females over the age of twenty $(3.5 \%)(p<0.001)$. Regarding education and search for the service, the pro- portions found as a whole are different. However, there is a growing trend between education and search for the service. As education increases, it also increases the number of women seeking abortions earlier $(82.5 \%-p<0.001)$.

The marital status is significant $p<0.001$, indicating that single females took longer to seek the abortion service.

When the aggressor is unknown $(60.7 \%-p$ $<0.001)$ or when there were multiple aggressors $(62.2 \%$ - $p<0.047)$, the trend was the pregnant females seek for abortion earlier. The use of physical

Table 3. Distribution of female victims of rape as a category of gestational age and sociodemographic characteristics, São Paulo, 1994-2013.

\begin{tabular}{|c|c|c|c|c|c|}
\hline \multirow{4}{*}{ Variables } & \multicolumn{3}{|c|}{ Category of Gestational Age (weeks) } & \multirow{4}{*}{$\begin{array}{c}\text { Total } \\
1270 \\
(100.0 \%)\end{array}$} & \multirow{4}{*}{ p* } \\
\hline & \multirow{3}{*}{$\begin{array}{c}<13 \\
680 \\
(53.5 \%)\end{array}$} & \multirow{3}{*}{$\begin{array}{c}13-22 \\
514 \\
(40.5 \%)\end{array}$} & \multirow{3}{*}{$\begin{array}{c}23 \\
76 \\
(6.0 \%)\end{array}$} & & \\
\hline & & & & & \\
\hline & & & & & \\
\hline Age (years) & & n (\%) & & & \\
\hline$>10<20$ & $238(44.8)$ & $243(45.8)$ & $50(9.4)$ & $531(100.0)$ & \multirow{2}{*}{$<0.001$} \\
\hline$\geq 20$ & $442(59.8)$ & $271(36.7)$ & $26(3.5)$ & $739(100.0)$ & \\
\hline \multicolumn{6}{|l|}{ Education } \\
\hline Illiterate & $31(36.1)$ & $49(57)$ & $6(7)$ & $86(100.0)$ & \multirow{7}{*}{$<0.001$} \\
\hline $\begin{array}{l}\text { Did not complete } \\
\text { elementary school }\end{array}$ & $193(46.1)$ & $197(47.0)$ & $29(7)$ & $419(100.0)$ & \\
\hline $\begin{array}{l}\text { Completed } \\
\text { elementary school }\end{array}$ & $68(55.3)$ & 49 (39.9) & $6(4.9)$ & $123(100.0)$ & \\
\hline $\begin{array}{l}\text { Did not complete } \\
\text { high school }\end{array}$ & $113(50.7)$ & $88(39.5)$ & $22(9.9)$ & $223(100.0)$ & \\
\hline $\begin{array}{l}\text { Completed high } \\
\text { school }\end{array}$ & $171(62)$ & $94(34.1)$ & $11(4)$ & $276(100.0)$ & \\
\hline $\begin{array}{l}\text { Did not complete } \\
\text { higher education }\end{array}$ & $57(66.3)$ & $28(32.6)$ & $1(1.2)$ & $86(100.0)$ & \\
\hline College degree & $47(82.5)$ & $9(15.8)$ & $1(1.8)$ & 57 (100.0) & \\
\hline \multicolumn{6}{|l|}{ Race } \\
\hline Caucasian & 408 (55.1) & 291 (39.3) & $41(5.5)$ & $740(100.0)$ & \multirow{5}{*}{0.836} \\
\hline Black & $91(54.17)$ & $67(39.88)$ & $10(5.95)$ & $168(100.0)$ & \\
\hline Mixed & $165(49.70)$ & $144(43.37)$ & $23(6.93)$ & 332 (100.0) & \\
\hline Yellow & $2(40.00)$ & $3(60.00)$ & $0(0.00)$ & $5(100.0)$ & \\
\hline Indigenous & $14(56.00)$ & $9(36.00)$ & $2(8.00)$ & $25(100.0)$ & \\
\hline
\end{tabular}




\section{INTERNATIONAL ARCHIVES OF MEDICINE \\ Section: Global Health \& Health Policy \\ ISSN: 1755-7682}

\begin{tabular}{|c|c|c|c|c|c|}
\hline \multicolumn{6}{|l|}{ Marital status } \\
\hline Married & $114(67.1)$ & $55(32.4)$ & $1(0.6)$ & $170(100.0)$ & \multirow{5}{*}{$<0.001$} \\
\hline Single & 459 (51.57) & $367(41.24)$ & 64 (7.19) & $890(100.0)$ & \\
\hline Divorced & $70(67.31)$ & $32(30.77)$ & $2(1.92)$ & $104(100.0)$ & \\
\hline Widow & $12(66.67)$ & $6(33.33)$ & $0(0.00)$ & $18(100.0)$ & \\
\hline Ignored & $25(28.41)$ & $54(61.36)$ & $9(10.23)$ & $88(100.0)$ & \\
\hline \multicolumn{6}{|l|}{ Religion ** } \\
\hline Catholic & $356(55.37)$ & $251(39.04)$ & $36(5.60)$ & $643(100.0)$ & \multirow{4}{*}{0.149} \\
\hline Evangelic & $177(57.65)$ & $112(36.48)$ & $18(5.86)$ & 307 (100.0) & \\
\hline Other religions & $48(61.54)$ & 29 (37.18) & $1(1.28)$ & $78(100.0)$ & \\
\hline Not religious & $84(48.6)$ & $73(42.2)$ & $16(9.3)$ & $173(100.0)$ & \\
\hline \multicolumn{6}{|l|}{ Intimidation } \\
\hline Physical strength & $214(59)$ & $130(35.8)$ & $19(5.2)$ & $363(100.0)$ & \multirow{4}{*}{$<0.001$} \\
\hline Serious threat & $124(54.7)$ & $91(40.1)$ & $12(5.3)$ & $227(100.0)$ & \\
\hline $\begin{array}{l}\text { Physical strength plus } \\
\text { serious threat }\end{array}$ & $256(57.6)$ & 170 (38.2) & $19(4.3)$ & $445(100.0)$ & \\
\hline Rape of vulnerable & $86(36.6)$ & $123(52.3)$ & $26(11.1)$ & $235(100.0)$ & \\
\hline \multicolumn{6}{|l|}{ Aggressor category*** } \\
\hline Unknown & $478(60.7)$ & $282(35.8)$ & $28(3.6)$ & $788(100.0)$ & \multirow{3}{*}{$<0.001$} \\
\hline Relative & $68(36.4)$ & $95(50.8)$ & $24(12.8)$ & $187(100.0)$ & \\
\hline Known, not relative & $123(45.6)$ & $125(46.3)$ & $22(8.2)$ & $270(100.0)$ & \\
\hline \multicolumn{6}{|c|}{ Number of perpetrators $* * * *$} \\
\hline One & $608(40.6)$ & $466(53.0)$ & $73(6.4)$ & $1147(100.0)$ & \multirow{2}{*}{0.047} \\
\hline Multiple & $61(62.2)$ & $36(36.7)$ & $1(1.0)$ & $98(100.0)$ & \\
\hline \multicolumn{6}{|l|}{ Police report } \\
\hline Yes & $537(53.5)$ & $409(40.8)$ & $57(5.7)$ & $1003(100.0)$ & \multirow{2}{*}{0.659} \\
\hline No & $143(53.6)$ & 105 (39.3) & $19(7.1)$ & $267(100.0)$ & \\
\hline \multicolumn{5}{|c|}{$\begin{array}{l}\text { * Probability values of the chi-square test, adopting a } \\
\text { significance level of } 95 \% \text {. }\end{array}$} & \\
\hline$* * * 25$ cases with unk & ata & $* \star * *$ & s with unkr & lata & \\
\hline
\end{tabular}

strength, serious threat or both $(57.6 \%-p<0.001)$, led the females to seek early for the service. However, with respect to intimidation, vulnerable females seek abortion later $(52.3 \%-p<0.001)$.

The race, religion, number of aggressors, and police report factors were not significant $(p>0.05)$, suggesting no influence on the late arrival of the women at the service asking for abortion.
Therefore, the results concerning the analysis of the multiple multinomial regression model of the variables of the study showed that marital factors (single) ( $p=0.035$ for late gestational age), vulnerable condition ( $p=0.015$ for intermediate gestational age), aggression by a relative ( $p=0.016$ for intermediate gestational age and $p=0.002$ for late gestational age), and police report ( $p=0.029$ for late gesta- 
Table 4. Multinomial Logistic Regression Model to predict intermediate gestational age (13-22 weeks) and late age ( $\geq 23$ weeks) versus early gestational age (<13 weeks); Sao Paulo,1994-2013.

\begin{tabular}{|c|c|c|c|c|}
\hline \multirow{2}{*}{$\begin{array}{l}\text { Independent } \\
\text { variables }\end{array}$} & \multicolumn{2}{|c|}{$\begin{array}{l}\text { Intermediate gestational } \\
\text { age (13-22 weeks) }\end{array}$} & \multicolumn{2}{|c|}{$\begin{array}{l}\text { Late gestational } \\
\text { age ( } \geq 23 \text { weeks) }\end{array}$} \\
\hline & Prevalence ratio $(95 \% \mathrm{CI})$ & $p$ & Prevalence ratio $(95 \% \mathrm{CI})$ & $\mathrm{p}$ \\
\hline Age & $0.92(0.7-1.22)$ & 0.554 & $0.54(0.3-1.00)$ & 0.049 \\
\hline Education & $0.84(0.78-0.91)$ & $<0.001$ & $0.93(0.77-1.11)$ & 0.436 \\
\hline Race & $1.03(0.81-1.32)$ & 0.795 & $1.02(0.62-1.69)$ & 0.941 \\
\hline Marital status & $1.38(0.95-2.00)$ & 0.088 & $8.74(1.17-65.37)$ & 0.035 \\
\hline Religion & $1.04(0.94-1.17)$ & 0.440 & $1.09(0.87-1.36)$ & 0.455 \\
\hline \multicolumn{5}{|l|}{ Intimidation } \\
\hline Physical strength & 1 & - & 1 & - \\
\hline Serious threat & $1.08(0.75-1.56)$ & 0.672 & $0.75(0.35-1.67)$ & 0.491 \\
\hline $\begin{array}{l}\text { Physical strength plus } \\
\text { serious threat }\end{array}$ & $1.11(0.83-1.50)$ & 0.467 & $0.84(0.43-1.66)$ & 0.618 \\
\hline Rape of vulnerable & $1.64(1.10-2.45)$ & 0.015 & $1.65(0.80-3.41)$ & 0.174 \\
\hline \multicolumn{5}{|l|}{ Aggressor } \\
\hline Unknown & 1 & - & 1 & - \\
\hline Relative & $1.61(1.09-2.37)$ & 0.016 & $2.99(1.50-5.96)$ & 0.002 \\
\hline Known, not relative & $1.28(0.93-1.76)$ & 0.128 & $1.90(1.00-3.64)$ & 0.051 \\
\hline Number of perpetrators & $0.85(0.55-1.33)$ & 0.486 & $0.2(0.03-1.5)$ & 0.117 \\
\hline \multirow[t]{2}{*}{ Police report } & $1.13(0.84-1.53)$ & 0.425 & $1.95(1.07-3.56)$ & 0.029 \\
\hline & & & \multicolumn{2}{|c|}{ Confidence interval of $95 \%$} \\
\hline
\end{tabular}

tional age) are significant when associated with the delay in seeking legal abortion (Table 4).

\section{Discussion}

The survey results found a set of factors such as environmental, cultural and social, family relationships, and beliefs that are present when dealing with the delay in seeking legal abortion after an episode of sexual violence.

The data revealed characteristics of the studied population as follows: young women with low education, without partners, who suffered intimidation with threats in vulnerable conditions, and many of them were raped by relatives.

As education increases-illiterate (36.1\%) to completed higher education (82.5\%) (Table 3)-it also increases the number of females who abort early, what could be understood as a dose/response effect, i.e. having a larger dose of education results in earlier arrival. However, we cannot say that education influences earlier arrival since it could provide a higher socioeconomic level that also interferes with seeking an abortion; or a pregnant female with lower education and restricted to public health care could not delay her arrival asking for an abortion just because of her education, but because of the need to look for a reference centre that effectively solves the problem since generally the other services do not provide abortions. For this reason, we cannot conclude that there is a direct cause/effect relationship. Silva et al. (2012) have also indicated low education as variable associated to induced abortion [14].

Two hundred and thirty-five cases (18.5\%) represented a vulnerable condition: 95 were less than 14 
years old (40.4\%), 69 had a mental illness (29.3\%), and 71 were raped under the effect of a substance that acts on the central nervous system (CNS) (30.3\%). This condition was statistically significant, suggesting that the greater the vulnerability of females $(p=0.015)$ (Table 4$)$, the greater the delay in seeking the service.

Younger ages and mental illness are conditions under which rape victims do not understand what happened, also leading them to be unaware of pregnancy. This situation also highlights additional violence that these young people suffer-neglect by their caregivers. In regard to the other 71 females who were under the influence of chemicals, they also hide the aggression suffered in addition to the resulting pregnancy. In general, the lack of guidance and care of the family is evident.

Recent findings showed that rape of a vulnerable person was almost four times more common among adolescents. Being less than 14 years old was predominantly responsible for the status of vulnerable person in adolescents, whereas in the adult group mental illness was the most common factor [15].

Of all the factors investigated herein, the assailant emerged as the highest statistically significant variable, suggesting that among the 1,270 women who came to the health service requesting legal abortion, 788 (62.05\%) were unaware of who attacked them, but 457 females (35\%) knew the perpetrator of the rape. The aggressor was known in 270 cases $(21.26 \%)$ and was a relative in 187 cases (14.72\%) (Table 3).

This fact provokes, therefore, deep reflection about these cases of kinship: 31 biological fathers, 44 stepfathers, 39 current intimate partners, 44 former intimate partners, 24 uncles, 10 brothers-inlaw, 19 brothers, and 20 cousins raped these young females who became pregnant, a situation exacerbated by the possibility that they could have interfered with the decision to carry out a legal abortion under safe conditions, either by complete disregard and ignorance of the pregnancy, or by threatening them in any way.

Bruschini [16] examines the broad and contradictory question: "What is family?" highlighting the importance of dissolving its appearance of naturalness, perceiving it as a mutable human creation and observes that the relations we often know as a marital relationship, kinship network, and domestic/ residential unit may present as very different institutions in other societies or in different historical moments.

Groups of individuals different by gender and age relate daily, often cohabiting the same space, creating a complex and dynamic web of emotions. Sexuality, reproduction, and socialization are spheres potentially generating both pleasurable as well as conflicting relations. The internal division of roles may be the expression of important relationships of domination and submission. It creates a distribution of privileges, rights, and duties within a group. It is, therefore, a space for possible changes, new ideas, and new habits that should be observed in the family dynamic, which creates conditions for the slow and gradual transformation of society [16].

A study conducted in 1990 at the Medical Legal Institute in São Paulo had 548 victims (49.64\%) who said they knew their attacker, 249 (22.55\%) who were victims of sexual assault by a relative, and 207 (18.75\%) cohabited with the offender [17].

When an incestuous relationship between fatherdaughter and stepfather-stepdaughter occurs, we must consider that family roles have changed: the father acts as if he were the daughter's husband, the woman accepts losing her function as wife and mother, and the daughter must also function as wife and mother of the brothers. In any case, the perpetrator of an incestuous act is assessed as mentally ill or as having a personality disorder and the responsibility should fall on the family as a whole and not only on the aggressor and his victim, since all of the family is complicit in such a situation [17]. 
Martins and Jorge [18] claim that as important as the diagnosis and appropriate care to children and adolescents who suffer sexual violence, the course of proceedings in the courts for children and youth and the criminal courts also contributes to the reduction of violence to determine measures of child protection and penalize the aggressor, preventing further aggression. The intervention of the courts for childhood and youth regarding situations of violence against children and adolescents is crucial since it has the conditions to terminate abuse through measures such as removal of paternal power, determination of treatment for abusive families, interdiction of habitation and contact with the child, or even through imprisoning the aggressor [18].

The condition that all the females surveyed had suffered serious threat, with or without physical force, assumes that such a situation has led to fear, silencing them about abuse and pregnancy. Threat, embarrassment, and humiliation are key factors to hide the sexual violence that occurred.

There are consistent data that the problem of underreporting worsens when the perpetrator is known by the victim, as in intrafamilial sexual abuse during childhood or adolescence. In these cases, the perpetrator takes advantage of his privileged position in the family, the authority and awe that is invested to ensure that chronic abuse remains hidden for long periods, a mechanism known as a covenant of silence [19].

Drezett [20] reinforces that women and children/ adolescents in situations of sexual violence face many obstacles to reveal what happened. There are different reasons for this reaction: fear of a negative reaction from family or a partner; afraid to face the offender in court; feelings of humiliation, shame, and guilt for not having reacted; fear of disrespectful treatment from the police or the forensic examination; fear of being discredited, even at health services; fear that their situation will become public and that they will be stigmatized; and fear of a death threat by the perpetrator if something is reported to the police [20].

Chen et al. (2010) showed in a systematic review of 37 eligible studies evidence for association between sexual abuse and an increased risk of a lifetime diagnosis of multiple psychiatric disorders, such as anxiety disorder, depression, eating disorders, posttraumatic stress disorder, sleep disorders, and suicide attempts. Associations persisted regardless of the victim's sex or the age at which abuse occurred [21]. Such disorders can also be indicated as possible reasons for underreporting the abuse and the pregnancy.

Concerning stigmatization, the females who have suffered an act of sexual violence meet female and male police officers, who can be empathetic towards them or can blame them, depending on the police station they go to report the sexual assault. Other situation is that often health professionals, when in the care of them, try to shift the "problem" to reference services, to the judiciary, to the public safety sector or to a social service institution. Many of these professionals are not trained to deal with the testimonies of sexual violence of women, which reinforces the need for the guidance of legal and regulatory instruments, such as constitutional rules, code of professional ethics, federal laws, ministerial decrees, agreements and international human rights [22].

The fact that females have registered a complaint and submitted a police report (or not) did not interfere in their late decision for legal abortion $(p=0.659)$ (Table 4). However, taking into account the high number of known offenders (relatives), it is understandable why a complaint was not formalized by the police department.

Drezett and Pedroso [23] clarify that the realization of abortion in cases of pregnancy resulting from sexual violence does not require judicial authorization nor depends on the opening of criminal proceedings or of the sentencing of the perpetrator, if there is any. A female who suffers sexual violence 
has no legal duty to report the incident to the police and is not obligated to submit a police report or complete a medical-legal examination. Nevertheless, she must be supported to take the appropriate legal measures. If she does not do it, for justifiable reasons, there is no legal basis to deny abortion [24].

The authors also point out that even with all the rigour adopted by health services, there is speculation that an abortion that does not require a police report would favour irregular access to abortion in cases of false allegation of a sexual crime. Data controlled by Hospital Pérola Byington show that almost $80 \%$ of females requesting abortion in cases of rape have spontaneously presented a police report. In addition, about $90 \%$ of those who enter without the document agree to complete the communication to the police when they are informed and supported. The number of females who refused to make a police report is very small and, in most cases, justified by the threat of death they suffer from the aggressors if they reveal the incident to the police [24].

About 1.5 million abortions are induced each year in clandestine conditions in Brazil. It is estimated that at least one young Brazilian dies every two days from such complications. Worldwide more than 40 million abortions occur each year. Treating abortion as a crime does not reduce the number of abortions or prevents foetal loss, but maintains the perverse precarity of health clandestinity, making it effective for killing women. The problem worsens in pregnancy resulting from rape, when health services deny, without justification, a safe and legal abortion [20].

In this context, there is also the refusal of professionals to perform abortions because of conscientious objection. The Ministry of Health, through the Norma Técnica Atenção Humanizada ao Abortamento (Technical Standard for Humane Abortion (are), determined that the claim of conscientious objection by referral services does not fit in cases of the "need for abortion because of a life- threatening situation; in any situation of abortion legally allowed (by court order), in the absence of another doctor to do so and when there is a risk of a woman suffering damage or health problems due to omission of medical care and complications from insecure abortion, because they are cases of urgency" [4].

Abortion in the case of pregnancy resulting from rape exempts legal authorization in Brazil; however, doctors continue to claim conscientious objection to avoid providing abortions. Nonetheless, the emergency room cannot be denied to a female, and state and health services managers are required to hire and maintain professionals who do not show this kind of objection in public hospitals and referral centres.

The fact that we have a restrictive law on abortion-yet listed in the penal code as a crime against life-contributes to the fear of health professionals. There is a lack of knowledge by professionals on the question of the interpretation of this legal framework. There are concerns, such as a woman can lie to obtain an abortion, and the doctor may be complicit in this. Abortion is very stigmatized, being a tense issue for females and any obstacle may be a reason to not seek an abortion [4].

Sociopolitical initiatives on violence in general have failed to respond to challenges like bringing domestic and/or sexual violence to light, better understanding the production process of violence to train competent and socially committed professionals in this fight, recovering families and victims, and preventing a family from becoming abusive, among others [25].

In about 49 countries laws include the indication of second trimester abortion if the pregnancy resulted from rape, and half of them are developed countries. Fifty-seven per cent of these countries define time limits for such abortions. The shorter time limit may reflect the belief that a female should be able to get an abortion for a pregnancy resulting from rape earlier than for other reasons. 
However, there is evidence that females can take a long time to report the rape. Some countries also require more than the affirmation of women that pregnancy resulted from a sexual crime. In Bolivia, a legal process must have been started. In Cameroon, there must be a certificate from the Public Ministry. In Hong Kong, a woman must make a police report. In Zimbabwe, the request must be submitted to the authorities. In at least 12 other countries there is the necessity of an approval requirement by a committee or two or more physicians [26].

The lack of information in Brazil is not only among women; it is also among health professionals in general. There are campaigns on domestic violence, but not on sexual violence. States and municipalities are responsible for disclosing emergency care units and hospitals that are permitted to conduct legal abortion [4].

In Brazil, 419 chief police officers were interviewed between 2010 and 2011 and researchers found that there is a lack of staff trained to give the necessary care to adequately support females who suffer sexual violence in the police stations [4].

Considering all the difficulties that female victims of sexual violence face, there is still a lack of studies with evidence and public policy initiatives actually committed to the defence of the right to security and freedom not only for children and teenagers, but also for the entire population in which prevails a culture of citizenship, education also committed to sexuality, with moral and ethical values independent of religious dogma, and especially public health as a top priority, applying technical standards by qualified staff in order to comply with the laws in each health service.

It is also worth considering that the 187 offenders related to the females in this study could be seen either as the result of social changes, which point to a confusion of values with the loosening of family ties that reinforce gender differences, or as paedophiles, psychopaths, or victims of poverty and alcoholism.
The variance of the gestational age of women seeking legal abortion is supposed to be related to difficulties in access to health services and barriers to disclosure of violence and pregnancy, as the condition of vulnerability and limiting the autonomy of people with mental illness, beyond the possibility of a woman's physical integrity being threatened or being under threat by a family member, if they reported the incident [27].

The literature suggests aspects indirectly associated with this delay, such as the implementation of sex education and reproductive health, ending impunity for perpetrators, decriminalization of abortion, facilitating access to early and safe abortion by decreasing unnecessary legal restrictions, in addition to greater training and exchange of information among multidisciplinary teams to optimize processes, prioritizing the interests of pregnant women.

Considering the issue of sexual violence, Brazilian legislation has advanced in the last decade, but the social structure remains fragile in health services for pregnant women that are victims of sexual abuse. Stigmatization by moral aegis and unscientific beliefs, how abortion and sexuality are still treated in Brazilian society, inhibits an important social discussion about hundreds of new monthly cases of young females being raped by their own relatives, as well as the importance of the implementation of educational programs that work to prevent new cases of violence and the promotion of clarification on the rights of victims of sexual abuse.

Therefore, the postponement in the search for legal abortion resulting from sexual violence was associated with low education and females in a vulnerable condition in pregnancies between 13 and 22 weeks. In the cases that gestational age has exceeded 22 weeks, the delay in seeking the health services was associated to females without intimate partners and those who made the police report. In both groups, assailants related to the victims were associated to the later arrival to the health service. 
Seeking legal abortion in gestational age between 13 and 22 weeks is directly implicated in the eligibility criteria for the abortion method, limiting the intrauterine aspiration methods and making induction with misoprostol the main choice. The method, although effective and safe for most women, requires longer period of hospitalization and increased suffering, especially by their common discomforts. On the other hand, the late arrival of the victim, after 22 weeks of gestation, makes it technically impossible to carry out the abortion, with all the consequences in maintaining forced pregnancy until term.

Public policies for sexual and reproductive health could include the conditions of highest fragility for women in pregnancy resulting from rape situation found in this study, and improve measures of earlier access to health services able to interrupt the pregnancy in an ethical, legal and safe basis.

\section{Conclusion}

Females without partners, who suffered intimidation with threats, in a vulnerable condition, who made a police report and, above all, who were raped by relatives, composed the group who took longer to get the health service.

\section{Competing interests}

The authors declare that they have no competing interests.

\section{Authors' contributions}

MTB, JD, GSM, VXP, RDR, FRO, LFT, FWSF, LSP, VSJ, $F A$, and LCA participated in the acquisition of data and revision of the manuscript. MTB, JD, GSM, VXP, RDR, LFT, VSJ, and LCA conceived of the study and determined the design. MTB, JD, FA, FRO, FWSF, LSP, RDR, VSJ, and LCA performed the statistical analysis, interpreted the data, and drafted the manuscript. All authors read and gave final approval of the version submitted for publication.

\section{Acknowledgements}

This study received financial support from Faculdade de Medicina do ABC.

\section{References}

1 Drezett J, Blake M de T, Lirab KSF de, Pimentel RM, Adami F, Bessab MMM, Abreu LC de: Doenças sexualmente transmissíveis em mulheres que sofrem crimes sexuais. Reprod Clim 2012, 27: 109-116. [doi: 10.1016/j.recli.2013.03.004]

2. Ministério da Saúde. Secretaria de Atenção à Saúde. Departamento de Ações Programáticas Estratégicas. Área Técnica de Saúde da Mulher. Prevenção e Tratamento dos Agravos Resultantes da Violência Sexual Contra Mulheres e Adolescentes. 2nd edition. Updated and expanded. Brasília-DF; 2005:68.

3. Van Look PFA, Cottingham JC: Unsafe abortion: an avoidable tragedy. Best Pract Res Cl Ob 2002, 16: 205 -220.

4. Pouza $A B$, Pessoa GS, Cortêz N: Dor em dobro. Agência de Reportagem e Jornalismo Investigativo Pública. 29 May, 2014. [http://apublica.org/2014/05/dor-em-dobro-2/]

5. Ministério da Saúde: $7^{\circ}$ Anuário Brasileiro de Segurança Pública. Brasil: Fórum Brasileiro de Segurança Pública; 2013.

6. Sedgh G, Singh S, Henshaw SK, Bankole A: Induced abortion: incidence and trends worldwide from 1995 to 2008. Lancet 2012, 379: 625 -632.

7. Ministério da Saúde. Secretaria de Políticas de Saúde. Departamento de Ações Programáticas Estratégicas. Área Técnica de Saúde da Mulher. Prevention and Treatment of Damages Resulting from Sexual Violence Against Women and Adolescents: Technical Standard. 3rd edition. Brasília-DF: Editora do Ministério da Saúde; 2011: 123.

8. Vertamatti MAF et al. Time lapsed between sexual aggression and arrival at the brazilian health service. Journal of Human Growth and Development 2013; 23(1): 46-51 
9. Blake MT, Drezett J, Machi GS, Pereira VX, Raimundo RD, Oliveira FR, Sarubbi-Jr V, Adami F, Abreu LC de: Factors associated to late-term abortion after rape: literature review. Reprod Clim 2014. [http://dx.doi.org/10.1016/j.recli.2014.08.003]

10. Organización Mundial de La Salud. Necesidades de Salud de los Adolescentes (Série Informes Técnicos, 609). Geneva: OMS; 1977.

11. Delmanto C, Delmanto R, Delmanto-Jr R, Delmanto FMA (Eds): Código Penal Comentado. São Paulo: Saraiva; 2010.

12. Barros AJ, Hirakata VN: Alternatives for logistic regression in cross-sectional studies: an empirical comparison of models that directly estimate the prevalence ratio. BMC Med Res Methodol 2003, 20: 21.

13. Kleinbaum D, Kupper L, Nizam A, Muller KE. Applied Regression Analysis and Other Multivariable Methods. 4th edition. Australia: Thomson Brooks/Cole; 2008.

14. Silva RS et al. Prevalence and characteristics of women with abortion among women with history of pregnancies. J. Hum. Growth Dev. 2012; 22(1): 27-33.

15. Blake $M$ de $T$, Drezett J, Vertamatti MF, Adami F, Valenti VE, Paiva AC, Viana JM, Pedroso D, Abreu, LC de.: Characteristics of sexual violence against adolescent girls and adult women. BMC Women's Health 2014, 14:15. [doi:10.1186/1472-6874-14-15]

16. Bruschini C: Teoria crítica da família. In Infância e Violência Doméstica: Fronteiras do Conhecimento. 6th edition. Edited by Azevedo MA, Guerra VN de A. São Paulo: Cortez; 2011.

17. Cohen C: O incesto. In Infância e Violência Doméstica: Fronteiras do Conhecimento. 6th edition. Edited by Azevedo MA, Guerra VN de A. São Paulo: Cortez; 2011.

18. Martins CB de G, Jorge MHP de M: Desfecho dos casos de violência contra crianças e adolescentes no poder judiciário. Acta Paulista de Enfermagem 2009, 22. [http://www.unifesp.br/ acta/artigo.php? volume $=22 \&$ ano $=2009$ \& numero $=6$ \&item $=12$ ]

19. Conselho Regional de Medicina de São Paulo. Violência sexual e aspectos éticos da assistência. In Cadernos de Ética em Ginecologia e Obstetrícia. 2nd edition. São Paulo: CREMESP; 2002:71-78

20. Associação de Ginecologia e Obstetrícia do Distrito Federal. Atendimento Integral às Vítimas de Violência Sexual: Orientações do Advogado e da Ginecologista. Revista SCOB, Brasília; Jan/ Feb 2014, 20. [http://www.sgob.org.br/novo/uploads/revista/ principal/5a8d4-SGOB-95.pdf]

21. Chen LP, Murad MH, Paras ML, et al. Sexual Abuse and Lifetime Diagnosis of Psychiatric Disorders: Systematic Review and Metaanalysis. Mayo Clinic Proceedings 2010;85(7):618-629. doi: 10.4065/mcp.2009.0583.

22. Souza CM, Adesse L. Sexual violence in Brazil: perspectives and challenges. Brasília: Secretaria Especial de Políticas para Mulheres; 2005.

23. Drezett J, Pedroso D: Aborto e violência sexual. Cienc Cult São Paulo 2012, 64.
24. Ministério da Saúde. Aspectos Jurídicos do Atendimento às Vítimas de Violência Sexual - Perguntas e Respostas para Profissionais de Saúde. Brasília: Ministério da Saúde; 2005:20.

25. Azevedo MA, Guerra VN de A. Infância e Violência Doméstica: Fronteiras do Conhecimento. 6th edition. São Paulo: Cortez; 2011.

26. Boland R: Second trimester abortion laws globally: actuality, trends and recommendations. Reprod Health Matter 2010, 18:67-89. [doi: 10.1016/S0968-8080(10)36521-9)]

27. Drezett J, Baldacini I, Freitas GC, Pinotti JA: Contracepção de emergência para mulheres vítimas de estupro. Revista do Centro de Referência 1998, 3: 29-33.

\section{Comment on this article:}

\section{f 18 in $8+\boldsymbol{S} P$}

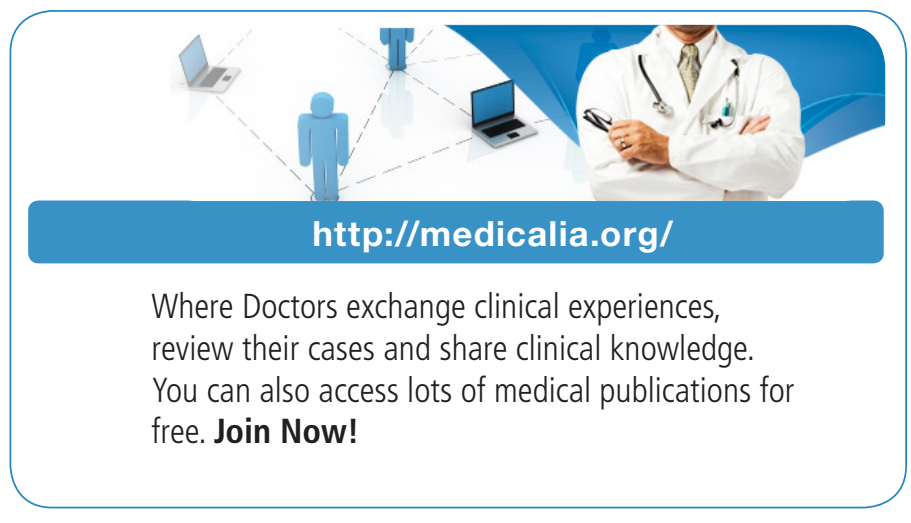

\section{Publish with iMedPub}

\section{http://www.imed.pub}

International Archives of Medicine is an open access journal publishing articles encompassing all aspects of medical science and clinical practice. IAM is considered a megajournal with independent sections on all areas of medicine. IAM is a really international journal with authors and board members from all around the world. The journal is widely indexed and classified Q1 in category Medicine. 